\title{
Syntomus pallipes (Dejean, 1825) (Coleoptera: Carabidae) - ground beetle new to Belarus
}

\author{
Oleg AleKSANDrOWICZ, ${ }^{1}$ ArTSIOM OSTROVSKY² \\ ${ }^{1}$ Institute of Biology and Environment protection of Pomeranian University, Arciszewskiego 22b, 76-200 Słupsk, Poland, e-mail: oleg. \\ aleksandrowicz@apsl.edu.pl \\ 2 Gomel State Medical University, Lange str. 5, 246000, Gomel, Belarus, e-mail: Arti301989@mail.ru
}

\begin{abstract}
Keywords Coleoptera, Carabidae, Syntomus pallipes (Dejean, 1825), new record, SE Belarus
Abstract Syntomus pallipes (Dejean, 1825) was recorded for the first time in Belarus from Gomel city (SE Belarus).

Syntomus pallipes (Dejean, 1825) - nowy gatunek dla fauny Białorusi z rodziny biegaczowatych (Coleoptera: Carabidae)

Słowa kluczowe Coleoptera, Carabidae, Syntomus pallipes (Dejean, 1825), pierwsza rejestracja, południowo-wschodnia Białoruś

Streszczenie Syntomus pallipes (Dejean, 1825) został odnotowany po raz pierwszy na Białorusi w Homlu (Białoruś południowo-wschodnia).
\end{abstract}

\section{Introduction}

The genus Syntomus Hope 1838 includes 52 wide dispersed mainly tropical species (Lorenz, 2005). There are 38 species known in Palaearctic region (Kabak, 2003), in Europe - 16 species, and 4 - in Middle Europe (Persohn, 2004). Nowadays 2 species only was known in Belarus (Aleksandrowicz, 2014).

S. pallipes occurs in Eurasia and North Africa. Its range takes whole temperate and steppe zones of Eurasia: from Netherlands to the Russian Far East. In the forest zone, it is very seldom, in the steppe - more common (Persohn, 2004).

Based on the author's research conducted in the south-eastern Belarus Syntomus pallipes was found to occur in the country. 


\section{Material and methods}

Locality: Belarus - Gomel city, (UTM UD61) (Figure 1).

The species new for the Belarus fauna: Syntomus pallipes (Dejean, 1825): Gomel, Auerbah str., 11.03.2016, 9 ex., in dry plant remains in the garden; ad lucem, 16.04.2016, 11 ex.; Gomel, Central City Park, sand beach of Sozh river, 28.05.2017, 2 ex., leg. A. Ostrovsky. Two specimens were with fully development wings, 20 - wingless. A material was collected by the second author by hand in 2016-2017.

\section{Discussion}

According to Kabak (2003) S. pallipes is distributed from North Africa and southern Europe, through the Balkans and Asia Minor to Central Asia, East Siberia and Far East.

In Central Europe occurs, but in most cases only single, in the south and south-east. From Germany, in addition to the current guidelines of Saxony, there are only old or questionable findings (Persohn, 2004). There are only old dates in Poland - more than 100 years ago (Burakowski et al., 1974; http://baza.biomap.pl/en/taxon/species-syntomus_pallipes/mapb). S. pallipes not found yet in north Ukraine (Putchkov, 2011).

It is interesting, that $S$. pallipes was known from large cities: Prague (Veselý, 2002) and Vienna (Hepner et al., 2008). We found all specimens in Gomel - a comparatively large city too.

Environmental requirements of $S$. pallipes are poorly known. According Persohn (2004) it prefers dry steppe habitats or light forests from lowlands to foothills. Koch (1989) considers it as an eurybiont.

According Persohn (2004) the wings are predominantly reduced. In our material $91 \%$ of specimens were wingless.

It is very rare everywhere. In Poland and Germany it has been placed on red lists of endangered species (Pawłowski et al., 2002; Schmidt et al., 2016). In Upper Silesia it is known as the extinct (Kuśka, 2007).

\section{Conclusion}

Nowadays, there are three species of the genus Syntomus Hope, 1838 known from Belarus, namely S. foveatus (Geoffroy in Fourcroy, 1785), S. pallipes (Dejean, 1825), S. truncatellus (Linnaeus, 1761).

$S$. pallipes is the next steppen species found in the south-eastern Belarus last decades. There were Calosoma investigator (Illiger, 1798), C. denticolle (Gebler, 1833), Harpalus subcylindricus (Dejean, 1829), H. honestus (Duftschmid, 1812), Zabrus tenebrioides (Goeze, 1777) (Aleksandrowicz, 2011) and Lebia marginata (Geoffroy, 1785) (Halinouski et al., 2015). 


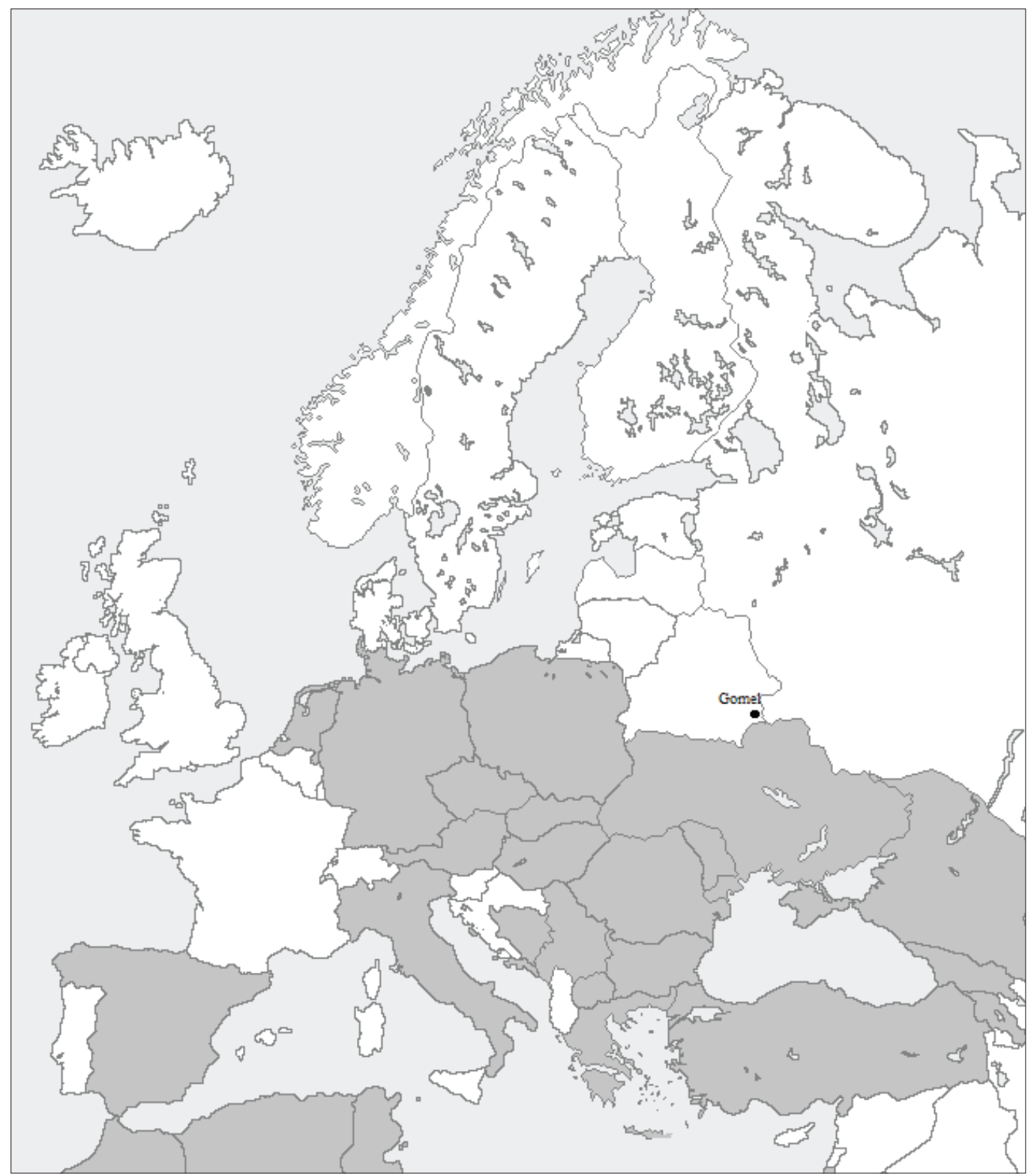

Figure 1. Distribution map of Syntomus pallipes in West Palaearctic region (according Vigna Taglianti 2013) with new date from Belarus (gray - species occurs, white - absent, black dot - new date)

Source: https://fauna-eu.org. 


\section{References}

Aleksandrowicz, O. (2011). Recent records of steppe species in Belarus, first indications of a steppe species invasion? ZooKeys, 100, 475-485.

Aleksandrowicz, O. (2014). Ground beetles (Coleoptera, Carabidae) west of the forest zone of the Russian Plain. Fauna, zoogeography, ecology, faunogenesis. Saarbrücken: Lambert Academic Publishing.

Burakowski, B., Mroczkowski, M., Stefańska, J. (1974). Chrzaszcze-Coleoptera. Biegaczowate-Carabidae 2. Katalog Fauny Polski. Cz. 23, t. 3. Warszawa: PWN.

Halinovsky, M.G., Kritskaya, A.N., Kabysheva, A.A. (2015). Rare and new species of beetles (Coleoptera) of the Gomel region for the fauna of Belarus. In: O.V. Yanchurevich et al. (eds.), Proceedings of the International Scientific and Practical Conference (Grodno, April 22-24, 2015) (pp. 69-70). Grodno: Grodno State University.

Hepner, M., Milasowszky, N., Strodl, M.A. (2008). Beiträge zur Spinnen- und Laufkäferfauna Wiens (Arachnida, Araneae; Coleoptera, Carabidae): Untersuchungen einer Wiese und einer Ruderalfläche im Bezirk Innere Stadt. Beiträge zur Entomofaunistik, 9, 51-65.

http://baza.biomap.pl/en/taxon/species-syntomus_pallipes/mapb.

Kabak, I. (2003). Tribe Lebiini Bonelli, 1810. In: I. Löbl, A. Smetana (eds.), Catalogue of Palaearctic Coleoptera, Vol. 1: Archostemata-Myxophaga-Adephaga (pp. 408-439). Stenstrup: Apollo Books.

Koch, K. (1989). Die Käfer Mitteleuropas. Ökologie. Krefeld: Goecke \& Evers Verlag.

Kuśka, A. (2007). Koleopterofauna Górnego Śląska i jej związki z fauną Czech i Moraw. In: J.A. Lis, M.A. Mazur (eds.), Przyrodnicze wartości polsko-czeskiego pogranicza jako wspólne dziedzictwo Unii Europejskiej (pp. 29-35). Opole: Centrum Studiów nad Bioróżnorodnością, Uniwersytet Opolski.

Lorenz, W. (2005). A systematic list of extant ground beetles of the world (Coleoptera "Geadephaga”: Trachypachidae and Carabidae incl. Paussinae, Cicindelinae, Rhysodinae). 2nd edition. Germany: Tutzing.

Pawłowski, J., Kubisz, D., Mazur, M. (2002). Coleoptera Chrząszcze. In: Z. Głowaciński (ed.), Czerwona Lista zwierząt ginacych i zagrożonych w Polsce (pp. 88-100). Kraków: Polska Akademia Nauk, Instytut Ochrony Przyrody.

Persohn, M. (2004). 112. Syntomus Hope. In: G. Müller-Motzfeld (ed.), Die Käfer Mitteleuropas. Adephaga 1. Carabidae (Laufkäfer). Bd. 2 (pp. 472-474). Heidelberg: Spektrum.

Schmidt, J., Trautner, J., Müller-Motzfeld, G. (2016). Rote Liste und Gesamtartenliste der Laufkäfer (Coleoptera: Carabidae) Deutschlands. 3. Fassung, Stand April 2015. Naturschutz und Biologische Vielfalt, 70 (4), 139-204.

Veselý, P. (2002). Střevliikoví brouci Prahy (Coleoptera: Carabidae). Die Laufkäfer Prags (Coleoptera, Carabidae). Praha: Clarion Production.

Vigna Taglianti, A. (2013). Fauna Europaea: Coleoptera, Carabidae. Fauna Europaea version 2.6. Retrived from: http://www.fauna-eu.org.

Cite as: Aleksandrowicz, O., Ostrovsky, A. (2017). Syntomus pallipes (Dejean, 1825) (Coleoptera: Carabidae) - ground beetle new to Belarus. Acta Biologica, 24, 15-18. DOI: 10.18276/ab.2017.24-02. 